\title{
Correction to: Introduction to Research on Identifications
}

\section{Correction to:}

J. Kubera, Identifications of French People of Algerian Origin, Palgrave Politics of Identity and Citizenship Series https://doi.org/10.1007/978-3-030-35836-5_1

The original version of this chapter was revised and the textual corrections given by the author has been incorporated. In Table 1.3, we have added comma and ' $d$ ' in the name as Mouss Benia ${ }^{\text {c,d }}$. Under the table, we have added the point ' $d$ ' with an explanation sentence as below: 'Being an Algerian immigrant is confirmed in the case of one of the author's parents

The updated version of the chapter can be found at https://doi.org/10.1007/978-3-030-35836-5_1 


\section{C2 Correction to}

Table 1.3 Authors of the analysed texts. Division into those raised in Algeria or in France, and in an Algerian or Algerian-French family

\begin{tabular}{|c|c|c|}
\hline \multirow[b]{2}{*}{ Where raised } & \multicolumn{2}{|l|}{ Socialisation } \\
\hline & Algerian family & Algerian-French family \\
\hline in Algeriaa & $\begin{array}{l}\text { Mehdi Charef } \\
\text { Zahia Rahmani } \\
\text { Samira Sedira }\end{array}$ & $\begin{array}{l}\text { Karim Amellal } \\
\text { Nina Bouraoui }\end{array}$ \\
\hline in France & $\begin{array}{l}\text { Azouz Begag } \\
\text { Ahmed Djouder } \\
\text { Faïza Guène } \\
\text { Ahmed Kalouazb } \\
\text { Razika Zitounic } \\
\text { Mouss Beniac,d }\end{array}$ & Tassadit Imache \\
\hline
\end{tabular}

${ }^{a}$ Authors of whom it is known that they were raised for at least several years in Algeria

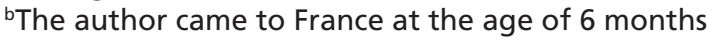

'The birthplaces and places of early socialisation of these authors was not established, though it is probable that they were only, or mainly, raised in France ${ }^{\mathrm{d} B e i n g}$ an Algerian immigrant is confirmed in the case of one of the author's parents 